\section{KEGIATAN PENYULUHAN BUDIDAYA IKAN AIR TAWAR OLEH KELOMPOK TANI SEJIWA DI JORONG VI SORIK, KABUPATEN PASAMAN}

Jurnal Pendidikan Luar Sekolah

http://kolokium.ppj.unp.ac.id/

Jurusan Pendidikan Luar Sekolah

Fakultas Ilmu Pendidikan

Universitas Negeri Padang

Sumatera Barat, Indonesia

Volume 5, Nomor 2, Oktober 2017 DOI: $10.24036 /$ kolokium-pls.v5i2.27

\author{
Ilham Andiski,2, Wirdatul Aini', Vevi Sunarti ${ }^{1}$ \\ ${ }^{1}$ Jurusan Pendidikan Luar Sekolah Fakultas Ilmu Pendidikan Universitas Negeri Padang \\ 2Email: ilhamandiski@yahoo.co.id
}

\begin{abstract}
ABSTRAK
Penelitian ini dilatarbelakangi oleh pelaksanaan kegiatan penyuluhan budidaya ikan air tawar oleh Kelompok Tani Sejiwa. Jenis penelitian ini adalah deskriptif kuantitatif. Teknik pengambilan sampel dalam penelitian ini adalah metode random sampling. Populasinya berjumlah 40 orang, sampel dalam penelitian ini berjumlah 30 orang. Teknik penarikan sampel yang digunakan adalah rumus persentase. Alat pengumpulan data adalah angket. Temuan dalam penelitian terlihat bahwa (1) strategi penyuluhan terhadap budidaya ikan air tawar oleh kelompok tani sejiwa di Jorong VI Sorik tergolong baik, (2) metode penyuluhan budidaya ikan air tawar oleh kelompok tani sejiwa di Jorong VI Sorik sudah dilakukan dengan baik, (3) evaluasi penyuluhan budidaya ikan air tawar oleh kelompok tani sejiwa di Jorong VI Sorik tergolong baik. Disarankan agar ketua dan anggota kelompok yang melakukan Kegiatan Budidaya Ikan Air Tawar untuk memasarkan hasil produksi di daerah lain, sehingga hasil yang didapat anggota kelompok lebih maksimal.
\end{abstract}

Kata Kunci: Penyuluhan, Budidaya Ikan, Kelompok Tani

\title{
PENDAHULUAN
}

Pembangunan pada era modrenisasi ini sangatlah penting demi mengikuti perkembangan zaman dan peningkatan strata ekonomi. Pada hakikatnya hidup dalam masyarakat di saat sekarang membutuhkan pembangunan yang mengacu kepada pencapaian tujuan kesejahteraan manusia. Pembangunan merupakan suatu upaya untuk pemenuhan kebutuhan dasar manusia, baik secara individual maupun kelompok, dengan cara-cara yang tidak menimbulkan kerusakan, baik terhadap kehidupan sosial maupun lingkungan sosial (Trijono, 2007).

Pentingnya pembangunan di era modernisasi ini semestinya diiringi dengan peningkatan kualitas pendidikan. Kualitas pendidikan menjadi sesuatu yang penting sebab pendidikan adalah pembelajaran yang dipersiapkan untuk meningkatkan pelaksanaan pekerjaan pada masa yang akan datang atau meningkatkan seseorang untuk dapat menerima tanggung jawab atau tugas-tugas baru (Atmodiwirio, 2002). Sasaran utamanya adalah peningkatan kualitas hidup manusia agar dapat menjadi penggerak perubahan (agent of change) dan agen pembangunan bangsa. 
Pendidikan berada pada posisi sentral untuk pembangunan sebab pendidikan berperan dalam pembentukan watak manusia untuk hal spiritual keagamaan, pengendalian diri, kepribadian, kecerdasan, dan akhlak mulia. Pendidikan juga berperan dalam peningkatan keterampilan setiap warga negara dan masyarakat. Pendidikan Luar Sekolah (PLS) merupakan salah satu jalan untuk melengkapi proses pendidikan bagi warga negara yang tidak mendapatkan kesempatan untuk memperoleh pendidikan formal di sekolah. Dalam konteks ini, pendidikan luar sekolah dipandang sebagai pengganti pendidikan formal di sekolah bagi orang yang putus sekolah, atau tidak melanjutkan sekolah ke jenjang pendidikan selanjutnya (Pratiwi \& Wibhawa, 2015).

Sudjana (dalam Pratiwi \& Wibhawa, 2015) menyatakan bahwa pendidikan luar sekolah adalah setiap usaha yang dilakukan secara sadar, sengaja, teratur dan terencana yang bertujuan untuk membantu peserta didik dalam mengembangkan dirinya sehinnga terwujud manusia yang gemar belajar. PLS dikenal pula sebagai pendidikan nonformal, yang dipahami sebagai bentuk jalur pendidikan yang turut berperan dalam peningkatan kualitas manusia. Hal ini sesuai dengan pendapat Coombs (dalam Hasan \& Nurhayati, 2012) sebagai berikut.

Pendidikan nonformal adalah setiap kegiatan terorganisasi dan sistematis diluar sistem persekolahan yang mapan dilakukan secara mandiri atau merupakan bagian penting dari kegiatan yang luas yang sengaja dilakukan untuk melayani peserta didik tertentu di dalam mencapai tujuan belajarnya.

Sanapiah (2007), program pendidikan luar sekolah bila disimak aneka ragam programnya, akan tampak tertuju ke arah dua muara, yaitu untuk pembelajaran kaum tertinggal sehingga terbebas dari ketidaktahuan dan untuk pembelajaran kaum tersingkir (kaum miskin) sehingga terbebas dari kemiskinan (ketertinggalan).

Kegiatan pendidikan luar sekolah adalah mencakup berbagai program yang diorganisasi dan direncanakan secara matang, serta program-program yang tidak direncanakan secara terinci (insidental). Program-program terencana, misalnya program paket A, B, dan C, Pendidikan Anak Usia Dini (PAUD) yang diselenggarakan dalam bentuk kelompok bermain (play group). Sedangkan, program yang tidak terencana (insidental), misalnya kegiatan kelompok wirid di mesjid dan penyuluhan pertanian.

Penyuluhan kepada kelompok tani misalnya, adalah berperan dalam peningkatan pengetahuan petani terhadap teknologi pengolahan dan hasil pertanian, serta penambahan informasi-informasi mutakhir di bidang pertanian yang berguna untuk peningkatan kesejahteraan petani beserta keluarganya (Koampa, L.S, Sendow, \& Moniaga, 2015). Peranan penyuluhan dalam memberikan pengetahuan kepada petani dapat berfungsi sebagai proses penyebarluasan informasi kepada petani dan proses penerangan atau memberikan penjelasan, dan proses perubahan perilaku petani (sikap, pengetahuan, dan keterampilan), serta sebagai proses pendidikan. Penyuluhan dilakukan dengan tujuan untuk peningkatan kualitas dan kuantitas produksi tanaman yang dibudidayakan petani serta dapat menyejahterakan petani (Saadah, Sulili, \& Deserama, 2011).

Upaya untuk mengembangkan potensi petani serta menambah dan memperluas wawasan pengetahuan, maupun keterampilannya yang berguna bagi petani atau warga masyarakat pada umumnya mencakup berbagai bidang dalam kehidupan. Salah satu bidang peningkatan pengetahuan masyarakat adalah dalam bidang pertanian. Upaya pembinaan terhadap masyarakat dalam bidang pertanian dapat dilakukan melalui penyuluhan pertanian 
yang diberikan petugas Penyuluhan Pertanian Lapangan (PPL) kepada para petani ataupun kelompok-kelompok di wilayah kerjanya.

Kusnadi (2011), penyuluhan pertanian adalah upaya menyampaikan informasi (pesan) yang berkaitan dengan bidang pertanian oleh penyuluh pertanian kepada petani beserta anggota keluarganya, baik secara langsung maupun tidak langsung agar mereka tahu, mau dan mampu menggunakan inovasi teknologi pertanian baru. Umumnya pesan terdiri dari sejumlah simbol dan isi pesan inilah yang memperoleh perlakuan. Bentuk perlakuan tersebut memilih, menata, menyederhanakan, menyajikan dan lain-lain. Simbol yang mudah diamati dan paling banyak digunakan yaitu bahasa. Keputusan-keputusan yang dibuat oleh penyuluh pertanian atau sumber untuk memilih serta menata isi pesan dan simbol yang digunakan pada pesan dapat dikatakan teknik penyuluhan pertanian.

Pendidikan luar sekolah berfungsi sebagai pengganti, penambah, dan pelengkap pendidikan formal dalam rangka pendidikan sepanjang hayat, maka dari itu penyuluhan dalam satuan PLS sangat membantu agar masyarakat mampu mandiri, berkembang secara optimal, menemukan pribadi individu atau mengenal kelebihan dan kekurangannya, mengenal lingkungan, atau membentuk individu agar dapat menyesuaikan diri dengan lingkungan sosial, ekonomi, budaya, serta alam yang ada, dan agar individu tersebut dapat merencanakan masa depannya (Hadi \& Anazifa, 2016).

Penyuluhan yang dilakukan kepada para petani berdampak bagi kesejahteraan hidup petani. Hal ini seperti yang terjadi pada para petani budidaya ikan di Kabupaten Pasaman Propinsi Sumatera Barat. Sebagai daerah dengan potensi perikanan darat (budidaya ikan air tawar) yang cukup besar, Kabupaten Pasaman mampu memenuhi kebutuhan pangan masyarakat, khususnya sumber daya hewani.

Daerah penghasil ikan air tawar salah satunya di Kabupaten Pasaman adalah Jorong VI Sorik Kecamatan Rao Kabupaten Pasaman. kapasitas produksi ikan tawar yang dihasilkan dari daerah ini adalah sebesar 7.364 tonsetiap tahunnya yang mampu memberikan suplai konsumsi untuk daerah-daerah seperti Sibolga, Padang Sidempuan, Panyabungan, Medan, Sipirok daerah di Sumatera Utara serta Bukittinggi dan Payakumbuh di Sumatera Barat. Potensi yang begitu besar dimiliki oleh daerah ini telah mendapat dukungan, baik secara teknis melalui beragam aktivitas peningkatan ekonomi maupun secara strategis melalui kebijakan pendidikan berupa penyuluhan yang ditujukan kepada kelompok tani budidaya ikan air tawar yang ada.

Penyuluhan pertanian tentang budidaya ikan air tawar dilakukan oleh Dinas Pertanian Kabupaten Pasaman melalui para penyuluh pertanian di Jorong VI Sorik Kecamatan Rao Kabupaten Pasaman pada Kegiatan penyuluhan dilaksankan selama tiga hari yaitu pada Selasa, 28 Juli-Kamis, 30 Juli 2015. Kegiatan bertujuan untuk menarik perhatian dan minat masyarakat khususnya dalam ternak ikan. Penyuluhan ditujukan untuk memberikan pengetahuan tentang perikanan kepada masyarakat, memperkenalkan teknologiteknologi cara beternak ikan yang benar, serta kebijakan untuk kolam baru dengan memberikan benih gratis. Selain kegiatan penyuluhan yang dilakukan, penyuluh pertanian juga melakukan kegiatan tindak lanjut berupa pembinaan melalui bantuan dalam pembangunan kolam baru dan pembagian benih ikan yang diberikan secara cumacuma/gratis oleh penyuluh pertanian Kabupaten Pasaman.

Sumber dari Dinas Pertanian Kabupaten Pasaman, kenaikan produksi budidaya ikan air tawar di Jorong VI Sorik Kecamatan Rao Kabupaten Pasaman cukup pesat yaitu berkisar 
11\% setiap tahun. Berdasar pada data tersebut, diketahui bahwa terdapat minat besar masyarakat untuk mengembangkan usaha budidaya ikan air tawar. Tentunya pertumbuhan produksi ini mengacu pada permintaan pasar yang terus meningkat. Hal ini tidak dapat dilepaskan dari kontribusi para penyuluh pertanian melalui kegiatan pendidikan luar sekolah yang dilakukan. Kegiatan dilakukan secara berkelanjutan kepada tiga kelompok tani di Jorong VI Sorik Kecamatan Rao Kabupaten Pasaman, yaitu Kelompok Tani Sejiwa, Kelompok Tani Tunas Harapan, dan Kelompok Tani Muda Berkarya.

Kelompok Tani Sejiwa yang merupakan kelompok tani memiliki prestasi lebih dibandingkan dua kelompok tani lainnya yang terdapat di Jorong VI Sorik Kecamatan Rao Kabupaten Pasaman. Hal ini diitunjukkan pada tabel berikut.

Tabel 1.

Data Hasil Pendapatan Anggota Kelompok Tani pada Tahun 2014 dan 2015 di Kecamatan Rao

\begin{tabular}{clcc}
\hline No & Nama Kelompok Tani & $\begin{array}{c}\text { Pendapatan Kelompok } \\
\text { Tahun 2014 }\end{array}$ & $\begin{array}{c}\text { Pendapatan Kelompok } \\
\text { Tahun 2015 }\end{array}$ \\
\hline 1. & Sejiwa & 250 ton & 337 ton \\
2. & Tunas Harapan & 82 ton & 95 ton \\
3. & Muda Berkarya & 78 ton & 76 ton \\
\hline
\end{tabular}

Sumber: Tim PPL Kecamatan Rao

Hasil pendapatan anggota kelompok tani sejiwa lebih unggul dibandingkan kedua kelompok tani lainnya, hal ini berdasarkan tabel pendapatan anggota kelompok tani dua tahun terakhir. Kelompok Tani Sejiwa beranggotakan 40 orang petani dan seluruh anggotanya telah sukses membudidayakan ikan air tawar. Keberhasilan Kelompok Tani Sejiwa terlihat dari hasil produksi dan kesejahteraan anggota kelompok tani dalam kesejahteraan hidup sehari-hari.

Informasi lebih lanjut diperoleh penulis melalui wawancara yang dilakukan dengan Bapak Zulfahmi (Ketua Kelompok Tani Sejiwa). Berdasarkan hasil wawancara tersebut diketahui bahwa kegiatan penyuluhan budidaya ikan yang dilakukan penyuluh terhadap kelompok tani dilakukan dengan baik, hal ini terlihat dari materi yang disampaikan penyuluh cukup mudah dipahami oleh anggota kelompok tani, sehingga anggota kelompok dapat menerapkan cara budidaya ikan yang benar dan terjadinya peningkatan produksi hasil panen (Wawancara, Rabu/15 Juli 2015).

Kegiatan penyuluhan berjalan dengan lancar, selanjutnnya didapatkan para petani anggota Kelompok Tani Sejiwa mengalami peningkatan produksi yang mencapai target yang telah ditentukan sebelumnya. Secara rinci dijelaskan bahwa modal untuk setiap $200 \mathrm{~kg}$ benih ikan adalah sebanyak Rp4.200.000,-, sedangkan pakan pelet untuk 40 karung adalah sama dengan Rp16.400.000,-, dan modal pokok adalah sebesar Rp20.600.000,-, diperoleh hasil panen sebesar Rp26.700.000,-. artinya terjadi peningkatan keuntungan sebesar 30\% dari modal atau sebesar Rp6.100.000,- (Wawancara dengan Bapak Zulfahmi, Ketua Kelompok Tani Sejiwa, Rabu/15 Juli 2015).

Penulis juga melakukan wawancara dengan Bapak Zalfadri, S.P (Tim Penyuluh Pertanian) pada Senin/27 Juli 2015, dari hasil wawancara tersebut diperoleh informasi sebagai berikut: 
Kegiatan Penyuluhan Budidaya Ikan Air Tawar oleh Kelompok...

1) Kegiatan penyuluhan dilaksanakan berdasarkan terdapatnya kebutuhan yang berasal dari masyarakat, khususnya 40 orang anggota Kelompok Tani Sejiwa di Jorong VI Sorik Kecamatan Rao Kabupaten Pasaman.

2) Penyuluhan berjalan dengan baik karena penyuluh memahami dan menguasai materi yang disampaikan, sehingga anggota kelompok cukup paham dan mengerti tentang penjelasan yang disampaikan penyuluh, serta tim penyuluh mampu menyampaikan strategi dan metode serta evaluasi penyuluhan yang dilaksanakan dengan baik.

3) Anggota kelompok bisa mengembangkan dan mempraktekkan pengetahuan yang didapat dari kegiatan penyuluhan untuk membudidayakan ikan air tawar. Biasanya sesuai dengan perkiraan penyuluh pertanian dan holtikultura di bidang perikanan di Kabupaten Pasaman, jika memasukkan bibit ikan $200 \mathrm{~kg}$, bisa menghasilkan panen dengan pakan ikan sebanyak 40 karung selama masa pembudidayaan ikan dua atau tiga bulan, maka akan menghasilkan panen 1,5 ton sampai 2,5 ton lebih, jika telah mencapai hasil yang demikian maka pembudidayaan ikan dikatakan berhasil atau meraup keuntungan yang besar. Keberhasilan kegiatan penyuluhan ini juga didukung oleh sarana dan prasarana yang memdai untuk diadakannya kegiatan penyuluhan oleh tim PPL di Jorong VI Sorik.

Lebih jelasnya keberhasilan yang diperoleh kelompok tani sejiwa dalam membudidayakan ikan air tawar dapat dilihat pada Tabel 2.

Tabel 2.

Pembudidayaan Ikan Mulai dari Benih, Pakan, dan Produksi pada Maret-April, Mei-Juni, Juli-Agustus Tahun 2015

\begin{tabular}{|c|c|c|c|c|c|c|}
\hline \multirow{2}{*}{ No } & \multirow{2}{*}{ Nama } & \multirow{2}{*}{ Bibit } & \multirow{2}{*}{ Pakan } & \multicolumn{3}{|c|}{ Hasil Produksi } \\
\hline & & & & Maret-April & Mei-Juni & Juli-Agustus \\
\hline 1. & Zulfahmi & $300 \mathrm{~kg}$ & $40 \mathrm{Sak}$ & 1,7 ton & 1,9 ton & 2 ton \\
\hline 2. & M. Nasbir & $200 \mathrm{~kg}$ & $35 \mathrm{Sak}$ & 1,3 ton & 1,4 ton & 1,5 ton \\
\hline 3. & Suardiman & $250 \mathrm{~kg}$ & $40 \mathrm{Sak}$ & 1,4 ton & 1,7 ton & 1,8 ton \\
\hline 4. & Sudirman & $100 \mathrm{~kg}$ & $18 \mathrm{Sak}$ & 1 ton & 1,3 ton & 1,5 ton \\
\hline 5. & Efrizal & $200 \mathrm{~kg}$ & $38 \mathrm{Sak}$ & 1,4 ton & 1,6 ton & 1,9 ton \\
\hline 6. & Dafnimal & $200 \mathrm{~kg}$ & $35 \mathrm{Sak}$ & 1,2 ton & 1,3 ton & 1,5 ton \\
\hline 7. & Erikmen & $250 \mathrm{~kg}$ & $40 \mathrm{Sak}$ & 1,3 ton & 1,4 ton & 1,5 ton \\
\hline 8. & M. Azwar & $100 \mathrm{~kg}$ & $17 \mathrm{Sak}$ & $986 \mathrm{~kg}$ & $997 \mathrm{~kg}$ & 1,1 ton \\
\hline 9. & Gunawan & $200 \mathrm{~kg}$ & $30 \mathrm{Sak}$ & $992 \mathrm{~kg}$ & 1 ton & 1,3 ton \\
\hline 10. & Dafnil & $230 \mathrm{~kg}$ & $35 \mathrm{Sak}$ & 1,2 ton & 1,4 ton & 1,5 ton \\
\hline 11. & Gusrizal & $200 \mathrm{~kg}$ & $41 \mathrm{Sak}$ & 1,2 ton & 1,5 ton & 1,7 ton \\
\hline 12. & Edi & $150 \mathrm{~kg}$ & $25 \mathrm{Sak}$ & $976 \mathrm{~kg}$ & 1 ton & 1,2 ton \\
\hline 13. & Abdul & $230 \mathrm{~kg}$ & $34 \mathrm{Sak}$ & 1,1 ton & 1,3 ton & 1,4 ton \\
\hline 14. & Wiwik & $220 \mathrm{~kg}$ & $37 \mathrm{Sak}$ & 1 ton & 1,1 ton & 1,3 ton \\
\hline 15. & Khairul & $170 \mathrm{~kg}$ & $27 \mathrm{Sak}$ & $982 \mathrm{~kg}$ & $997 \mathrm{~kg}$ & 1,1 ton \\
\hline 16. & Dodi Putra & $210 \mathrm{~kg}$ & $36 \mathrm{Sak}$ & 1 ton & 1,2 ton & 1,3 ton \\
\hline 17. & M. Nasir & $180 \mathrm{~kg}$ & $28 \mathrm{Sak}$ & $990 \mathrm{~kg}$ & 1,1 ton & 1,1 ton \\
\hline 18. & M. Naim & $250 \mathrm{~kg}$ & $40 \mathrm{Sak}$ & 1,3 ton & 1,4 ton & 1,5 ton \\
\hline 19. & Syamsul & $200 \mathrm{~kg}$ & $37 \mathrm{Sak}$ & 1 ton & 1,1 ton & 1,3 ton \\
\hline 20. & Zulharsim & $220 \mathrm{~kg}$ & $39 \mathrm{Sak}$ & 1 ton & 1,2 ton & 1,4 ton \\
\hline 21. & Rizki & $200 \mathrm{~kg}$ & $34 \mathrm{Sak}$ & 1,1 ton & 1,2 ton & 1,3 ton \\
\hline 22. & Gufron & $210 \mathrm{~kg}$ & $37 \mathrm{Sak}$ & 1,1 ton & 1,2 ton & 1,4 ton \\
\hline 23. & Irwan & $230 \mathrm{~kg}$ & $39 \mathrm{Sak}$ & 1,2 ton & 1,4 ton & 1,5 ton \\
\hline 24. & Rahmat & $250 \mathrm{~kg}$ & $40 \mathrm{Sak}$ & 1,4 ton & 1,5 ton & 1,7 ton \\
\hline 25. & Asnawel & $240 \mathrm{~kg}$ & $37 \mathrm{Sak}$ & 1,3 ton & 1,5 ton & 1,6 ton \\
\hline
\end{tabular}




\begin{tabular}{lcclccc}
26. & Reki & $180 \mathrm{~kg}$ & $30 \mathrm{Sak}$ & 1 ton & 1,1 ton & 1,3 ton \\
27. & Hendri & $250 \mathrm{~kg}$ & $37 \mathrm{Sak}$ & $1,3 \mathrm{ton}$ & 1,5 ton & 1,6 ton \\
28. & Basmin & $260 \mathrm{~kg}$ & $43 \mathrm{Sak}$ & $1,5 \mathrm{ton}$ & $1,7 \mathrm{ton}$ & 1,8 ton \\
29. & Tarmizan & $350 \mathrm{~kg}$ & $47 \mathrm{Sak}$ & 1,8 ton & 2,3 ton & 2,5 ton \\
30. & Bukhari & $300 \mathrm{~kg}$ & $50 \mathrm{Sak}$ & $1,7 \mathrm{ton}$ & 2 ton & 2,2 ton \\
\hline
\end{tabular}

Sumber: Ketua Kelompok Tani Sejiwa

Berdasarkan fenomena tersebut peneliti tertarik melakukan penelitian tentang Kegiatan Penyuluhan Budidaya Ikan Air Tawar oleh Kelompok Tani Sejiwa di Jorong VI Sorik Kecamatan Rao Kabupaten Pasaman. Dalam pelaksanaan penelitian ini penulis mempunyai tujuan yang hendak dicapai yaitu: (1) Untuk melihat strategi penyuluhan budidaya ikan air tawar di kelompok tani sejiwa, (2) Untuk melihat metode penyuluhan budidaya ikan air tawar dikelompok tani sejiwa, (3)Untuk melihat evaluasi penyuluhan budidaya ikan air tawar dikelompok tani sejiwa.

Adapun manfaat penelitian ini secara teoritis adalah (1) Sebagai masukan bagi pengembangan ilmu pengetahuan Pendidikan Luar Sekolah dan untuk menambah kemampuan masyarakat dalam berwirausaha membudidayakan ikan air tawar khususnya anggota kelompok tani sejiwa Jorong VI Sorik yang menjadi salah satu program Pendidikan Luar Sekolah. Dan manfaat Praktis adalah (1)Bagi tim PPL dapat memberikan kontribusi yang positif dalam pengembangan ilmu pengetahuan untuk kelompok tani sejiwa (2)Sebagai masukan untuk anggota tani sejiwa di Jorong VI Sorik agar lebih menigkatkan kinerjanya dalam berwirausaha. (3) Bagi penulis, hasil penelitian ini bisa memperdalam wawasan tentang berwirausaha khususnya di bidang budidaya ikan air tawar dan menjadi bahan untuk mengembangkan penelitian selanjutnya.

\section{METODE}

Penelitian ini merupakan penelitiankuantitatif dengan metode deskriptif. Melalui penelitian ini, penulis berusaha mendeskripsikan suatu gejala, kejadian, peristiwa yang terjadi dilapangan apa adanya tanpa melakukan penambahan atau intervensi terhadap sasaran penelitian. Pada penelitian ini variabel yang akan diteliti yaituKegiatan Penyuluhan Budidaya Ikan Air Tawar oleh Kelompok Tani Sejiwa di Jorong VI Sorik Kecamatan Rao Kabupaten Pasaman. Dilihat dari segi strategi, metode dan evaluasi.

Populasi dalam penelitian ini adalah anggota kelompok tani sejiwa berjumlah 40 orang. Teknik pengambilan responden dengan menggunakan random sampling karena pengambilan sampel anggota dari populasi dilakukan secara acak tanpa memperhatikan strata yang ada dalam populasi itu. Dengan demikian maka jumlah sampel dalam penelitian ini sebanyak $75 \%$ yaitu 30 orang. Teknik yang digunakan untuk mengumpulkan data pada penelitian ini adalah angket, sedangkan alat pengumpulan data yang digunakan adalah pernyataan. Analisis data dalam penelitian ini adalah untuk melihat Kegiatan Penyuluhan Budidaya Ikan Air Tawar Oleh Kelompok TaniSejiwadengan menggunakan rumus persentase. 
Kegiatan Penyuluhan Budidaya Ikan Air Tawar oleh Kelompok...

\section{HASIL PENELITIAN DAN PEMBAHASAN}

\section{Hasil Penelitian}

\section{Strategi Penyuluhan}

Rata-rata persentase responden yang menyatakan sangat memahami sebesar 54,81 $\%$, menyatakan memahami sebesar 31,93\%, menyatakan kurang memahami 8,60\%, dan menyatakan tidak memahami 4,35 \% terhadapStrategi Penyuluhan Budidaya Ikan Air Tawar oleh Kelompok Tani Sejiwa di Jorong VI Sorik Kecamatan Rao Kabupaten Pasaman. Untuk lebih jelasnya dapat dilihat pada histogram berikut.

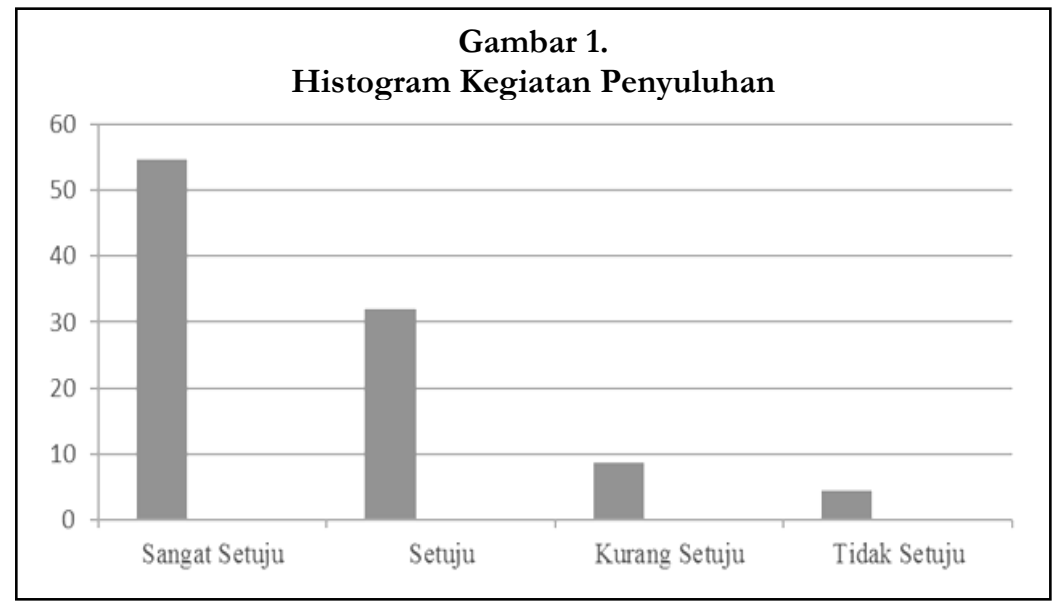

Penjelasan di atas dapat disimpulkan bahwa sebanyak 16 orang $(54,81 \%)$, responden menyatakan Sangat Setuju/SS dengan strategi penyuluhan yang dilakukan kelompok tanisejiwa dalam melakukan penyuluhan budidaya ikan air tawar.Hal ini diklasifikasikan pada kategori baik yang berarti seluruh anggota kelompok tani sejiwa telah melihat strategi penyuluhan budidaya ikan air tawar.

\section{Metode Penyuluhan}

Rata-rata persentase responden yang menyatakan sangat memahami sebesar 53,30 $\%$, menyatakan memahami sebesar 35,74\%, menyatakan kurang memahami 7,96 \%, dan menyatakan tidak memahami 2,80 \% terhadap Metode Penyuluhan Budidaya Ikan Air Tawar oleh Kelompok Tani Sejiwa di Jorong VI Sorik Kecamatan Rao Kabupaten Pasaman.Untuk lebih jelasnya dapat dilihat pada histogram berikut.

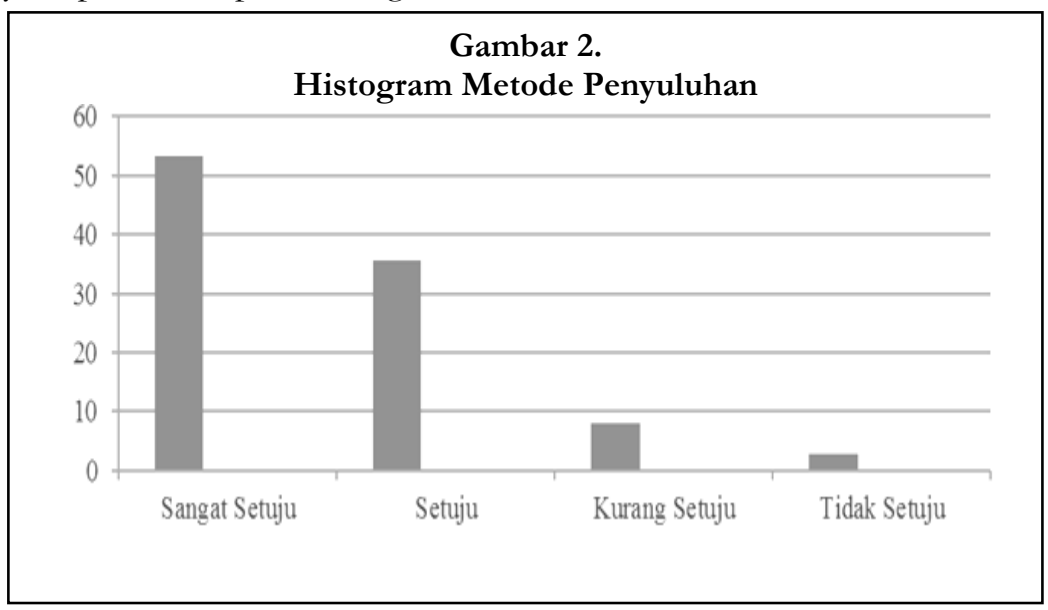


Penjelasan di atas dapat disimpulkan bahwa sebanyak 16 orang $(53,3 \%)$, responden menyatakan Sangat Setuju/SS dengan metode yang dilakukan kelompok tanisejiwa dalam melakukan penyuluhan budidaya ikan air tawar.Hal ini diklasifikasikan pada kategori baik yang berarti seluruh anggota kelompok tani sejiwa telah ikut dalam melakukan metode penyuluhan budidaya ikan air tawar.

\section{Evaluasi Penyuluhan}

Rata-rata persentase responden yang menyatakan sangat memahami sebesar 53,30\%, menyatakan memahami sebesar 35,74\%, menyatakan kurang memahami $7,96 \%$, dan menyatakan tidak memahami 2,80 \% terhadap Kegiatan PenyuluhanBudidaya Ikan Air Tawar oleh Kelompok Tani Sejiwa di Jorong VI Sorik Kecamatan Rao Kabupaten Pasaman. Untuk lebih jelasnya dapat dilihat pada histogram berikut.

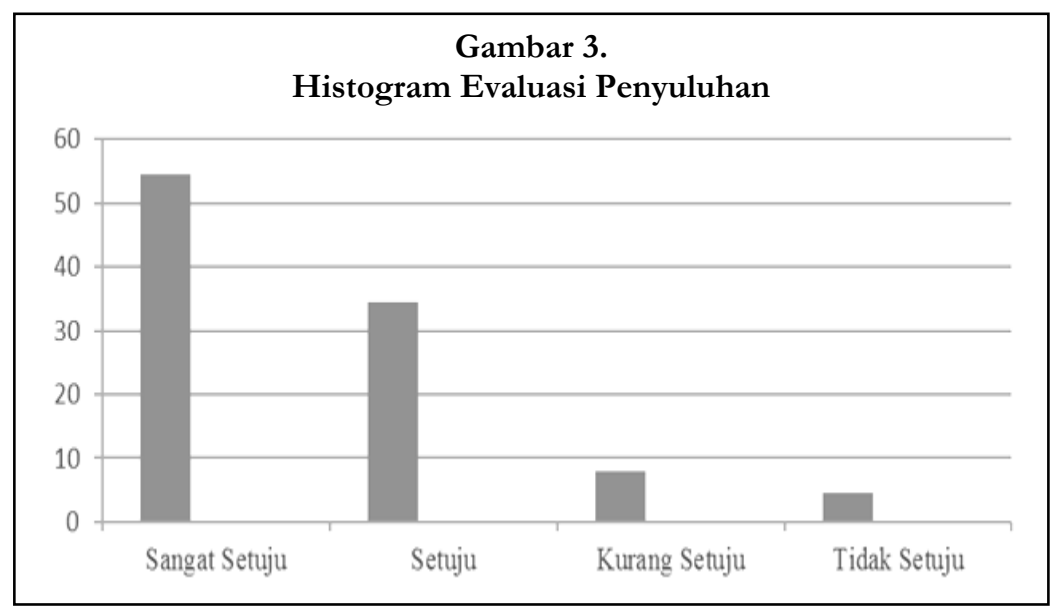

Penjelasan di atas dapat disimpulkan bahwa sebanyak 16 orang (54,55\%), responden menyatakan Sangat Setuju/SS dengan cara evaluasi dilakukan kelompok tani sejiwa dalam melakukan budidaya ikan air tawar. Hal ini diklasifikasikan pada kategori baik yang berarti sebagian besar anggota kelompok tani sejiwa ikut dalam melihat evaluasi budidaya ikan air tawar.

\section{Pembahasan}

\section{Strategi Penyuluh}

Berdasarkan hasil pengolahan data tentang gambaran kontrol orang tua terhadap remaja di lingkungan keluarga, hal ini ditandai sebagian besar responden yang menyatakan sering pada butir pernyataan yang telah disediakan peneliti, untuk jawaban sering dikategorikan baik. Jadi berdasarkan data di atas menunjukkan bahwa gambaran kontrol oleh orang tua terhadap remaja di lingkungan keluarga berada pada kategori baik di Jorong Tanjung Betung, Kecamatan Rao Selatan, Kabupaten Pasaman.

Hasil temuan penelitian dan hasil pengolahan data bahwa $(54,81 \%)$, anggota kelompok tani sejiwa sudah melihat strategi penyuluh budidaya ikan air tawar. Hal ini diklasifikasikan pada kategori baik yang berarti seluruh anggota kelompok tani sejiwa telah melihat strategi penyuluh budidaya ikan air tawar. Hasil dari rekapitulasi persentase 
sebelumnya maka dijelaskan bahwa anggota kelompok tani sejiwa mengetahui dan memahami dengan jelas bagaimana strategi penyuluh ikan dalam budidaya ikan air tawar.

Sapoetro (dalam Mardikanto, 1988), kunci pentingnya penyuluhan di dalam proses pembangunan didasari oleh kenyataan bahwa pelaksana utama pembangunan adalah masyarakat kecil yang umumnya termasuk golongan ekonomi lemah, baik lemah dalam permodalan, strategi, dan keterampilannya, maupun lemah dalam hal peralatan dan teknologi yang diterapkan. Di samping itu, mereka juga seringkali lemah dalam hal semangatnya untuk maju dalam mencapai kehidupan yang lebih baik.

Soekidjo (2003) menjelaskan bahwa strategi merupakan hasil tahu dan ini terjadi setelah orang melakukan penginderaan terhadap suatu obyek tertentu. Sebagian besar strategi manusia diperoleh melalui mata dan telinga. Strategi penyuluh pada kegiatan penyuluhan baik, hal tersebut dapat dilihat dari kemampuan penyuluh yang kreatif dalam menjelaskan materi tentang penyuluhan, peserta penyuluhan antusias untuk mengikuti kegiatan penyuluhan, dan keramahan penyuluh dalam berinteraksiu dengan kelompok tani sejiwa yang menjadi peserta penyuluhan. Kegiatan penyuluhan dalam hal pembenihan ini adalah suatu usaha yang dilakukan penyuluh untuk memberikan informasi kepada kelompok tani sejiwa yang masih lemah strateginya tentang bagaimana cara melakukan pembenihan yang baik dalam membudidayakan ikan air tawar dengan menggunakan inovasi teknologi baru.

\section{Metode Penyuluhan}

Hasil temuan penelitian dan hasil pengolahan data bahwa (53,30\%), anggota kelompok tani sejiwa melihat metode penyuluhan budidaya ikan air tawar. Hal ini diklasifikasikan pada kategori baik yang berarti seluruh anggota kelompok tani sejiwa telah metode penyuluhan budidaya ikan air tawar. Hasil rekapitulasi persentase sebelumnya maka dijelaskan bahwa anggota kelompok tani sejiwa melihat dengan jelas bagaimana proses metode budidaya ikan air tawar.

Saud (2009) mengatakan perencanaan sebagai proses penyusunan berbagai keputusan yang akan dilaksanakan pada masa yang akan datang untuk mencapai tujuan yang telah ditentukan. Perencanaan itu dapat pula diberi arti sebagai suatu proses pembuatan serangkaian kebijakan untukmengendalikan masa depan sesuai yang ditentukan. Jadi, perencanaan adalah proses penyusunan suatu kegiatan masa yang akan datang untuk mencapai tujuan yang telah ditentukan.

Penyuluhan dalam hal ini adalah suatu proses pembelajaran yang diberikan penyuluh kepada pelaku usaha atau kelompok tani sejiwa agar mampu mengorganisasikan untuk mengakses informasi-informasi sebagai upaya untuk meningkatkan produktivitas pengembangan budidaya ikan air tawar dengan anggota kelompok sejiwa lainnya sehingga memperoleh hasil yang maksimal (Indraningsih, Sugihen, Tjitropranoto, Asngari, \& Wijayanto, 2010).

Pengembangan adalah suatu usaha untuk meningkatkan kemampuan teknis, teoritis, konseptual, dan moral anggota kelompok sesuai dengan kebutuhan pekerjaan/jabatan melalui pendidikan dan latihan. Pendidikan meningkatkan keahlian teoritis, konseptual, dan moral anggota kelompok sedangkan latihan bertujuan untuk meningkatkan keterampilan teknis metode pekerjaan anggota kelompok, workshoop bagi anggota kelompok dapat meningkatkan strategi lebih lagi di luar perusahaan (Busono, 2016). 
Strategi diartikan langkah-langkah atau tindakan yang dilaksanakan untuk tercapainya suatu sasaran (misi) atau tujuan yang dikehendaki. Strategi penyuluhan senantiasa mengikuti perubahan yang terjadi (Prima, 2016). Jadi, strategi yang dimaksud dalam penelitian ini adalah tindakan atau langkah-langkah yang dibuat untuk mencapai suatu tujuan yang diinginkan. Lubis (2007), metode adalah cara yang digunakan untuk mencapai tujuan secaraefektif dan efisien. Metode penyuluhan berarti cara yang dipakai oleh penyuluh/instruktur agar tujuan penyuluhan dapat dicapai secara efektif dan efisien. Jadi, metode adalah cara yang sistematis digunakan untuk mencapai tujuan yang telah direncanakan.

Sikula (2000) mendefinisikan pengembangan sebagai berikut: "Pengembangan mengacu pada ketua dan anggota adalah suatu proses pendidikan jangka panjang menggunakan suatu prosedur yang sistematis dan terorganisasi ketua kelompok belajar strategi konseptual dan teoritis untuk tujuan umum". Sedangkan definisi latihan diungkapkan oleh Andrew E. Sikula yaitu "latihan adalah proses pendidikan jangka pendek dengan menggunakan prosedur yang sistematis dan terorganisir, sehingga anggota kelompok belajar strategi strategi pengerjaan dan keahlian untuk tujuan tertentu".

\section{Evaluasi Budidaya}

Hasil temuan penelitian dan hasil pengolahan data bahwa (54,55\%), anggota kelompok tani sejiwa melihat evaluasi budidaya ikan air tawar. Hal ini diklasifikasikan pada kategori baik yang berarti sebagian besar anggota kelompok tani sejiwa ikut melihat evaluasi budidaya ikan air tawar. Hasil dari rekapitulasi persentase sebelumnya maka dijelaskan bahwa anggota kelompok tani sejiwa melihat dengan jelas bagaimana evaluasi.

Penyuluhan adalah sebagai proses komunikasi pembangunan, penyuluh-an tidak sekadar upaya untuk menyampaikan pesan-pesan pembangunan, tetapi yang lebih penting dari itu, untuk menumbuh-kembangkan partisipasi masyarakat dalam pembangunan (Mardikanto, 1988). Dalam hal ini penyuluh sebagai proses komunikasi untuk menyampaikan cara produksi budidaya ikan air tawar yang baik sehingga anggota kelompok tani sejiwa mampu mengolah dan memasarkan hasil produksi budidaya ikan air tawar dari cara yang mereka peroleh dari penyuluhan yang diberikan oleh penyuluh PPL.

\section{KESIMPULAN}

Berdasarkan hasil penelitian yang telah diuraikan pada bab sebelumnya, maka dapat diambil kesimpulan bahwa: Pertama, kegiatan penyuluhan budidaya ikan air tawar di Kelompok Tani Sejiwa di Jorong VI Sorik Kecamatan Rao Kabupaten Pasamanditinjau dari aspek strategi penyuluhan, anggota kelompok sudah melihat strategi penyuluh budidaya ikan air tawar dengan baik, hal ini terlihat dari seluruh anggota kelompok tani sejiwa telah melihat strategi penyuluh budidaya ikan air tawar. Kedua, kegiatan penyuluhan budidaya ikan air tawar oleh Kelompok Tani Sejiwa di Jorong VI Sorik Kecamatan Rao Kabupaten Pasamanditinjau dari aspek metode penyuluhan, anggota kelompok tani sejiwa melihat metode budidaya ikan air tawar dengan baik, hal ini terlihat dari seluruh anggota kelompok tani sejiwa ikut dalam melihat metode kegiatan penyuluhan budidaya ikan air tawar. Ketiga, kegiatan penyuluhan budidaya ikan air tawar oleh Kelompok Tani Sejiwa di Jorong VI Sorik Kecamatan Rao Kabupaten Pasaman ditinjau dari aspek evaluasi penyuluhan, anggota kelompok tani sejiwa melihat evaluasi budidaya ikan air tawar berjalan dengan baik, hal ini 
Kegiatan Penyuluhan Budidaya Ikan Air Tawar oleh Kelompok...

dapat terilihat dari anggota kelompok tani sejiwa ikut dalam melihat evaluasi budidaya ikan air tawar.

\section{DAFTAR RUJUKAN}

Atmodiwirio, S. (2002). Manajemen Pendidikan Indonesia. Jakarta: Ardadizya.

Busono, G. A. (2016). Pengaruh Sistem Pelatihan dan Pengembangan Karyawan Terhadap Kinerja Karyawan PT. Persada Sawit Mas (PSM) Kecamatan Pampangan Kabupaten Ogan Komering Ilir. MUQTASHID, I(01), 81-114.

Hadi, R. F., \& Anazifa, R. D. (2016). Pendidikan Lingkungan Nonformal sebagai Upaya Meningkatkan Sikap Peduli Lingkungan pada Siswa. In Prosiding Symbion (Symposium on Biology Education), Prodi Pendidikan Biologi, FKIP, Universitas Ahmad Dablan, 27 Agustus 2016 (pp. 647-658).

Hasan, E. S., \& Nurhayati, S. (2012). Pendidikan Luar Sekolah. Jurnal Ilmiah Program Studi Pendidikan Luar Sekolah STKIP Siliwangi Bandung, 1(1), 5-31.

Indraningsih, K. S., Sugihen, B. G., Tjitropranoto, P., Asngari, P. S., \& Wijayanto, H. (2010). Kinerja Penyuluh dari Perspektif Petani dan Eksistensi Penyuluh Swadaya sebagai Pendamping Penyuluh Pertanian. Analisis Kebijakan Pertanian, 8(4), 303-321.

Koampa, M. V., L.S, B. O., Sendow, M., \& Moniaga, V. R. B. (2015). Partisipasi Kelompok Tani dalam Kegiatan Penyuluhan Pertanian di Desa Kanonang Lima, Kecamatan Kawangkoan Barat, Minahasa. Agri-Sosioekonomi, 11(3A), 19-32.

Kusnadi, D. (2011). Metode Penyuluhan Pertanian. Bogor: STPP Press.

Lubis, S. (2007). Sistem Komunikasi Indonesia. Medan: Bartong Jaya.

Mardikanto, T. (1988). Komunikasi Pembangunan. Surakarta: UNS Press.

Pratiwi, E. P., \& Wibhawa, B. (2015). Pengembangan Pendidikan Non Formal Melalui Program Keaksaraan Fungsional Pusat Kegiatan Belajar Masyarakat. Prosiding Penelitian Dan Pengabdian Kepada Masyarakat, 2(2), 169-174. https://doi.org/10.24198/jppm.v2i2.13274

Prima, F. (2016). Strategi Penyuluhan.

Saadah, Sulili, A., \& Deserama, R. B. (2011). Peranan Penyuluhan Pertanian Terhadap Pendapatan Petani yang Menerapkan Sistem Tanam Jajar Legowo. Jurnal Agrisistem, 7(2), 91-94.

Sanapiah, F. (2007). Pendidikan Luar Sekolah Menjawab Tugas Mulia Mengisi Pembangunan. Jakarta: Direktorat Jenderal Pendidikan Nonformal.

Saud, U. S. (2009). Pengembangan Profesi Guru. Bandung: Alfabeta.

Sikula, A. E. (2000). Manajemen Sumber Daya Manusia. Bandung: Erlangga.

Soekidjo, N. (2003). Penelitian Kesehatan. Jakarta: PT. Rineka Cipta.

Trijono, L. (2007). Pembangunan Sebagai Perdamaian. Jakarta: Yayasan Obor. 